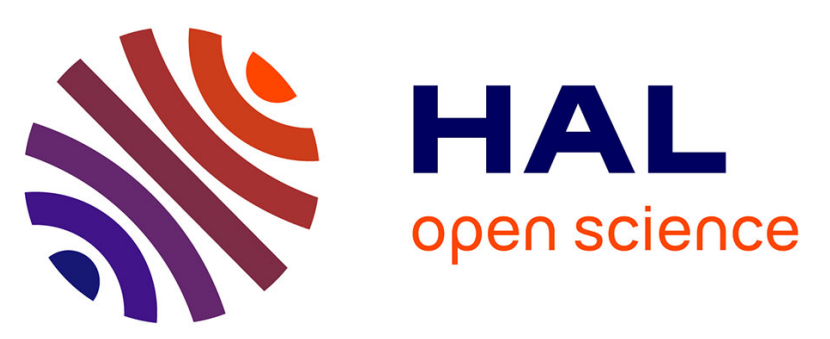

\title{
SOD1, ANG, VAPB, TARDBP, and FUS mutations in familial amyotrophic lateral sclerosis: genotype-phenotype correlations.
}

Stéphanie Millecamps, François Salachas, Cécile Cazeneuve, Paul Gordon, Bernard Bricka, Agnès Camuzat, Léna Guillot-Noël, Odile Russaouen, Gaëlle Bruneteau, Pierre-François Pradat, et al.

\section{To cite this version:}

Stéphanie Millecamps, François Salachas, Cécile Cazeneuve, Paul Gordon, Bernard Bricka, et al.. SOD1, ANG, VAPB, TARDBP, and FUS mutations in familial amyotrophic lateral sclerosis: genotype-phenotype correlations.. Journal of Medical Genetics, 2010, 47 (8), pp.554-60. 10.1136/jmg.2010.077180 . hal-00607332

\section{HAL Id: hal-00607332 \\ https://hal-unilim.archives-ouvertes.fr/hal-00607332}

Submitted on 31 Jul 2012

HAL is a multi-disciplinary open access archive for the deposit and dissemination of scientific research documents, whether they are published or not. The documents may come from teaching and research institutions in France or abroad, or from public or private research centers.
L'archive ouverte pluridisciplinaire HAL, est destinée au dépôt et à la diffusion de documents scientifiques de niveau recherche, publiés ou non, émanant des établissements d'enseignement et de recherche français ou étrangers, des laboratoires publics ou privés. 


\section{SOD1, ANG, VAPB, TARDBP, and FUS mutations in familial Amyotrophic}

\section{Lateral Sclerosis: genotype-phenotype correlations}

Stéphanie Millecamps ${ }^{1}$, François Salachas ${ }^{2}$, Cécile Cazeneuve ${ }^{3}$, Paul Gordon ${ }^{2}$, Bernard Bricka ${ }^{3}$, Agnès Camuzat ${ }^{1}$, Léna Guillot-Noël ${ }^{1}$, Odile Russaouen ${ }^{3}$, Gaëlle Bruneteau ${ }^{2}$, Pierre-François Pradat ${ }^{2}$, Nadine Le Forestier ${ }^{2}$, Nadia Vandenberghe $^{4}$, Véronique Danel-Brunaud ${ }^{5}$, Nathalie Guy ${ }^{6}$, Christel Thauvin-Robinet ${ }^{7}$, Lucette Lacomblez ${ }^{2,8}$, Philippe Couratier ${ }^{9}$, Didier Hannequin ${ }^{10}$, Danielle Seilhean ${ }^{1,11}$, Isabelle Le Ber $^{1}$, Philippe Corcia ${ }^{12}$, William Camu ${ }^{13}$, Alexis Brice $^{1,3}$, Guy Rouleau ${ }^{14}$, Eric LeGuern ${ }^{1,3}$ and Vincent Meininger ${ }^{2}$

${ }^{1}$ Centre de Recherche de l'Institut du Cerveau et de la Moelle, INSERM UMRS975, CNRS UMR7225, Université Pierre et Marie Curie-Paris 06, Hôpital Pitié-Salpêtrière, Paris, France.

${ }^{2}$ Assistance Publique Hôpitaux de Paris (AP-HP), Fédération des Maladies du Système Nerveux, Centre de référence maladies rares SLA, Hôpital Pitié-Salpêtrière, Paris, France.

${ }^{3}$ AP-HP, Département de Génétique et Cytogénétique, Unité Fonctionnelle de neurogénétique moléculaire et cellulaire, Hôpital Pitié-Salpêtrière, Paris, France.

${ }^{4}$ Hospices Civils de Lyon, Centre SLA de Lyon, Hôpital Neurologique Pierre Wertheimer, Lyon, France

${ }^{5}$ Centre SLA-MMN, Service de Neurologie et Pathologie du Mouvement, Hôpital Roger Salengro, CHRU

Lille, France.

${ }^{6}$ Service de neurologie du CHU Montpied, INSERM U929, Université Clermont 1, Clermont-Ferrand, France.

${ }^{7}$ Centre de Génétique, Hôpital d'Enfants, Dijon, France

${ }^{8}$ INSERM UMRS 678, Université Pierre et Marie Curie-Paris 06, Paris, France.

${ }^{9}$ Universite de Limoges, IFR 145 GEIST, Institut d'Epidemiologie Neurologique et de Neurologie Tropicale, Limoges, France.

${ }^{10}$ Service de Neurologie et CMRR, INSERM U614, Centre Hospitalier Universitaire, Rouen, France

${ }^{11}$ Département de Neuropathologie, AP-HP, Université Pierre et Marie Curie-Paris 06, Hôpital Pitié-Salpêtrière, Paris, France.

${ }^{12}$ Centre SLA, CHU de Tours, Université François Rabelais, Tours, France

${ }^{13}$ Centre SLA, CHU de Montpellier, Université Montpellier 1, France 
${ }^{14}$ Center of Excellence in Neuromics, Centre Hospitalier de l'Université de Montreal, and Department of Medicine, University of Montreal, Montreal, Quebec, Canada.

Word count in the text: 2971

Word count in the abstract: 245

Number of Tables/Figures: 2 Tables, 1 Figure and 3 supplementary files

Number of References: 35 (20 supplementary references are included in sppl. Table 1).

Correspondence to:

Dr Stéphanie Millecamps: stephanie.millecamps@upmc.fr

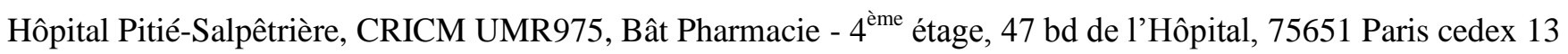
Tel: 33(1)42-17-75-59

Fax: 33(1)42-17-75-33

Licence for publication: The Corresponding Author has the right to grant on behalf of all authors and does grant on behalf of all authors, an exclusive licence (or non-exclusive for government employees) on a worldwide basis to the BMJ Publishing Group Ltd and its Licensees to permit this article (if accepted) to be published in Journal of Medical Genetics and any other BMJPGL products to exploit all subsidiary rights, as set out in our licence (http://group.bmj.com/products/journals/instructions-for-authors/licence-forms).

Competing interests: none declared 


\begin{abstract}
Background. Mutations in $S O D 1, A N G, V A P B, T A R D B P$ and $F U S$ genes have been identified in amyotrophic lateral sclerosis (ALS).

Methods. We estimated the relative contributions of the different mutations to ALS by systematically screening a cohort of 162 families enrolled in France and 500 controls (1000 chromosomes) using molecular analysis techniques and performing phenotype-genotype correlations.
\end{abstract}

Results. We found 31 pathogenic missense mutations in 36 patients (20 SOD1, 1 ANG, 1 VAPB, 7 TARDBP and 7 FUS). Surprisingly two FUS mutation carriers also harbored $A N G$ variants. We identified one family of Japanese origin with the P56S VAPB mutation. Seven novel mutations (3 in SOD1, 2 in TARDBP, 2 in FUS) were found. None of them was detected in controls. Segregation of detected mutations with the disease was confirmed in 11 families including 5 pedigrees carrying the novel mutations. Clinical comparison of SOD1, TARDBP, FUS and other FALS patients (with no mutation in the screened genes) revealed differences in site of onset (predominantly lower limbs for SOD1 and upper limbs for TARDBP mutations), age of onset (younger with FUS mutations) and in life span (shorter for FUS carriers). One third of SOD1 patients survived more than 7 years: these patients had earlier disease-onset than those presenting with more typical course. Differences were also observed among FUS mutations, with the R521H FUS mutation being associated with longer disease duration.

Conclusions. This study identifies new genetic associations with ALS and provides phenotype-genotype correlations with both previously reported and novel mutations.

Key words: ALS, family study, genetics, phenotype, mutation 


\section{Introduction.}

Recent genetic advances have brought to five the number of genes involved in typical amyotrophic lateral sclerosis (ALS). The first identified was the SOD1 gene, which encodes cooper/zinc superoxide dismutase.[1] More than 130 mutations, which account for 12-23\% of familial ALS (FALS), have now been reported (http://alsod.iop.kcl.ac.uk/Als/Index.aspx). A single mutation, c.166C>T/Pro56Ser (P56S), in the gene encoding VAMP (vesicle associated membrane protein) associated protein B (VAPB), was subsequently identified in Brazilian kindreds who shared a common founder from the time of the Portuguese colonization of Brazil.[2, 3] The recent discovery of mutations in the $A N G$ (angiogenin) [4], TARDBP (TAR DNA-binding protein 43) [5, 6, 7, 8, 9, 10, 11] and FUS (fused in sarcoma) [12,13] genes, all encoding proteins probably involved in RNA metabolism, have opened new areas of study into possible molecular mechanisms underlying ALS.

In the present study, we establish the frequencies of mutations in these five genes by systematically screening a cohort of 162 French patients with FALS, and compare the phenotypes related to the different mutations.

\section{Methods.}

Patients. The population comprised 162 index cases of unrelated families with probable or definite ALS[14], mainly of Caucasian origin (except three patients of Asian and one Sepharadic Jewish heritage). DNA samples were collected over the past 15 years at the ALS National Reference Center of Pitié-Salpêtrière Hospital (Paris). During the same period, the number of ALS patients followed up by the center was 6602. Relatives of some families for which we identified a mutation were collected by other French ALS Centers belonging to the French ALS study group. One hundred patients were male and 62 were female $(\mathrm{M}: \mathrm{F}$ ratio=1.61:1). Control samples were obtained from 500 healthy Caucasian individuals matched to the sex and age of the patients. Protocols were approved by the "Comite d'Ethique de la Pitié-Salpêtrière" and by the Medical Research Ethics Committee of "Assistance Publique-Hôpitaux de Paris". All participants signed a consent form for the research.

Molecular analysis. Coding regions and exon-intron boundaries of SOD1 (5 exons), ANG (exon 1 and 2), VAPB (5 exons), TARDBP (5 exons), and FUS (15 exons) genes were amplified from genomic DNA in 5, 3, 5, 6 and 13 fragments, respectively. Sequence of the primers and amplification conditions are available upon request. 
Clinical features. The following clinical data were collected: age at onset (first symptom of weakness), site of onset (upper limb, lower limb, bulbar), presence of cognitive impairment[15] and survival. For survival we used two variables bringing complementary information for mutation carriers: the disease duration (interval from onset to death or censoring) and life span (age at death or censoring), defined by the delay between birth and death. This parameter appeared informative in FALS patients as it could provide an insight on the duration of the whole disease process. Features recorded at the first clinical evaluation (initial signs) and at the last evaluation (final signs) were: predominance of lower (LMN) or upper motor neuron (UMN) involvement (according to El Escorial criteria)[14] and bulbar function (using the modified Norris bulbar scale).[16] To assess the degree of deterioration in bulbar function during the course of the disease, we calculated a bulbar score (difference between initial and final Norris bulbar scale scores).

Statistical analysis. Mean and median age of onset, disease duration and life span were determined using maximum likelihood estimates including censored data. Data were censored at the last date of analysis $(01 / 02 / 2010)$ if the patient was alive. The Cox proportional hazards regression model examined the relationship between potential predictors and the outcome of interest (either age at onset, disease duration or life span). Mutation status (SOD1, TARDBP, FUS, other FALS) was treated as a categorized variable. If the difference was significant ( $\mathrm{P}<0.05)$, a Log Rank analysis compared groups by pairs. A similar analysis compared disease duration in FUS patients carrying either the $\mathrm{R} 521 \mathrm{H}$ or other mutations. Proportions of patients classified according to gender, onset site, disease duration and presence/absence of cognitive impairment were compared by pairs between SOD1, TARDBP, FUS and other FALS groups using Fisher's exact tests. A Mann Whitney test compared mean age at onset between two subgroups of $S O D 1$ patients (with disease duration $>7$ or $\leq 7$ years) and mean disease duration in patients carrying the $\mathrm{R} 521 \mathrm{H}$ or other FUS mutation. One way analysis of variance (ANOVA) tests compared mean bulbar scores in SOD1, TARDBP and FUS patients. If the difference was significant $(\mathrm{P}<0.05)$, pairewise comparisons were made using a Tukey-Kramer post test. Statistical analyses were performed using the SPSS 11.0 data analysis software (SPSS Inc). 
Results.

Millecamps et al.

\section{Genetic data.}

We sequenced the SOD1, ANG, VAPB, TARDBP and FUS genes simultaneously in all patients.

We found 18 different SOD1 missense mutations in 20 out of the 162 FALS patients, corresponding to a mutation frequency of $12.3 \%$ (sppl. table 1). Table 1 summarizes the mutations we found and indicates the correspondence between the numbering of SOD1 mutations according to Human Genome Variation Society guidelines (http://www.hgvs.org/) and the ALS Online Database (http://alsod.iop.kcl.ac.uk/Als/index.aspx). Three patients harbored novel SOD1 mutations, that were not detected in controls and that affected a highly conserved residue until xenopus: c.139C >G/p.His47Asp (H46D), c.200C >G/p.Pro67Arg (P66R) and c.251A>G/p.Asp84Gly (D83G). The affected relatives were deceased so the segregation of H46D and P66R mutations could not be established. The D83G mutation was present in an affected brother of the index case, but not in the healthy sister (sppl. fig 1A).

Next, we identified the same c.122A>T/pLys41Ile (K17I) $A N G$ mutation in two families with dominant inheritance. The K17I mutation has been reported in 3 apparently healthy people, $[4,17]$ but was not detected in our 500 controls. We also found the c.232A $>$ G/p.Lys78Glu (K54E) and the c.434G >A/p.Arg145His (R121H) variants in two FALS, which were previously reported as mutations in sporadic ALS (SALS).[17, 18] In the present study however, these substitutions were not detected in the other affected relatives. One of the K17I carrier was later found to carry a R521C FUS mutation and the K54E carrier was found to carry a new FUS mutation (R521S), which segregated with the disease (sppl. fig $1 \mathrm{H})$.

We also identified the c.166C >T/p.Pro56Ser (P56S) VAPB mutation in one family, giving a mutation frequency of 0.6\%. The P56S carrier was of Japanese descent, and represents the first non-Brazilian patient carrying this mutation. Three other members of his family had motor neuron disease, suggesting autosomal dominant transmission. We did not detect any other variant of this gene in FALS. The finding of a P56S VAPB mutation in a patient of Japanese origin presumably reflects the Portuguese trading connection with the Far East and Brazil in the mid $16^{\text {th }}$ century.

Six different TARDBP missense mutations, all located in exon 6, were detected in 7 families (table 1), corresponding to a mutation frequency of $4.3 \%$. Pedigrees of the G295S, the A382T and the A315T substitutions have been described elsewhere.[6, 19] An additional family carrying the G348C mutation was identified. This mutation was 
detected in the mother of the index case, an obligate carrier who has not developed the disease at age 65 ( $\operatorname{sppl}$. fig $1 \mathrm{G}$ ). We also identified two novel mutations: the c.1150G>C/p.Gly384Arg (G384R) mutation in an affected woman, her affected sister, and in an obligate carrier aged 73 years who has not developed the disease but who has transmitted it to her affected son (sppl. fig 1E); and the c.1153T>G/p.Trp385Gly (W385G) mutation in two affected brothers of a separate family (sppl. fig $1 \mathrm{~F}$ ). These two novel mutations seemed to be pathogenic as they co-segregated with the disease, they were not detected in 500 controls and the amino acids targeted, Gly384 and Trp385, were conserved until xenopus.

We identified five different missense mutations in FUS in seven families. Two of these mutations were novel (table 1). The frequency of FUS mutations was $4.3 \%$ of our FALS patients. All FUS mutations were located in exon 15 . No mutation was found in controls. Four mutations (R521C, R521H, R521S, R521L) targeted the same arginine residue that is conserved until xenopus. The first novel FUS mutation was a c.1561C>A/p.Arg521Ser (R521S) substitution. The mutation was absent in the healthy sister of the index case but present in a far cousin who died from a bulbar ALS (sppl. fig 1H). The second novel mutation was a c.1562G>T/p.Arg521Leu (R521L) mutation. DNA samples of three healthy relatives (father and two aunts) did not bear the mutation, confirming that the disease was transmitted to the index case by her affected mother (sppl. fig 1I). In both families, the penetrance was incomplete as the disease was transmitted by obligate carriers who lived until the age of 73 and 77 without developing ALS. The already reported c.1561C $>$ T/p.Arg521Cys (R521C), c.1562G>A/p.Arg521His (R521H) and c.1542G>T/p.Arg514Ser (R514S) mutations were also detected. We confirmed the segregation of the R521H mutation (sppl. fig 1J) and showed, for the first time, the segregation of the R514S mutation (sppl. fig 1K). Surprisingly a FUS mutation was identified in two patients who also carried K17I or K54E $A N G$ variant (table 1).

\section{Clinical findings.}

Clinical data could be recovered for 100 relatives belonging to the 36 families with mutations and is summarized for 81 patients, from whom the information was the most complete, in supplementary table 2.

Age at onset for the SOD1, TARDBP, FUS and other FALS (with no mutation in the screened genes) groups was statistically different (table 2, Fig 1C). FUS patients had younger onset than SOD1 (Log Rank: p=0.0111) and other FALS (Log Rank: p<0.0001) patients. 
Life span for the SOD1, TARDBP, FUS and other FALS patient groups was significantly different (table 2, fig 1D). FUS patients had a shorter life span than SOD1 (Log Rank: $\mathrm{p}=0.0002)$, TARDBP (Log Rank: $\mathrm{p}=0.0028$ ) or other FALS (Log rank: $\mathrm{p}<0.0001)$ patients. The SOD1 and TARDBP groups were similar.

Disease duration of the SOD1, TARDBP, FUS and other FALS groups was different (table 2, fig 1E). The disease was more rapid in FUS than in SOD1 (Log Rank: p=0.0082), TARDBP (Log Rank: p=0.0019) or other FALS patients (Log rank: $\mathrm{p}=0.0425$ ). To further examine disease duration, we separated the mutated patients into three groups: "rapid course" (disease duration $<3$ years), "medium course" (3-7 years) and "slow course" ( $>7$ years). Our SOD1 patients had heterogeneous disease durations with bimodal distribution; more than half $(53 \%, \mathrm{n}=18)$ had a rapid course as in some patients carrying the novel H46D and D83G mutations. One third of SOD1 patients $(32 \%, \mathrm{n}=11)$ had slow disease progression (fig 1B). The average age at onset was lower in this group $(41.2 \pm 3.3, \mathrm{n}=11)$ than in patients with more rapid course $(56.4 \pm 2.3, \mathrm{n}=23$, Mann Whitney test: $\mathrm{p}=0.0017)$. Slow progression was notably observed in some patients with the novel P66R (>27 years) and D83G (>12 years) mutations and with the poorly documented N139D mutation. These patients typically had young onset and prominent LMN signs resembling progressive muscular atrophy. Long disease duration was also observed in the family with a VAPB mutation, who, as a whole, had leg onset in the sixth decade (sppl. table 2). Among the 15 patients with TARDBP mutations, only one presented with a slow course; two thirds (n=9) had a medium course and one third (n=5) developed rapid disease (fig 1B). No FUS patient had slow disease progression. More than $85 \%(\mathrm{n}=18)$ died after a rapid disease (fig 1B). Three patients with R521H mutations had a "medium course" leading to a disease duration longer for this FUS mutation than for the others (sppl. table 2, Log Rank: $\mathrm{p}=0.0213$, fig $1 \mathrm{~F})$. The percentage of patients in each disease duration subgroup $(<3,3-7,>7$ years) was compared between SOD1, TARDBP, FUS and other FALS patients using Fisher's exact test analyses. FUS patient distribution was different from that of SODI (Fisher's test: $\mathrm{p}=0.006$ ), TARDBP (Fisher's test: $\mathrm{p}=0.002$ ) and other FALS (Fisher's test: $\mathrm{p}=0.044)$. SOD1 patients distribution was also different from that of TARDBP (Fisher's test: $\mathrm{p}=0.0063$ ) and other FALS (Fisher's test: $\mathrm{p}=0.0005$ ).

The site of onset in FUS patients was in the arms $(43 \%, \mathrm{n}=9)$, legs $(38 \%, \mathrm{n}=8)$ or bulbar muscles $(19 \%, \mathrm{n}=4)$ which is similar to the other FALS groups. Site of onset (fig 1A) was mainly in the lower limbs for SOD1 (85\%, n=28/33, Fischer's exact test for the difference with FALS group: $\mathrm{p}<0.0001)$ and in the upper limbs for TARDBP patients (76.4\%, $n=13 / 17$, Fisher's exact test for the difference with FALS group: $\mathrm{p}=0.04)$. Initial and final predominance of UMN or LMN signs in the limbs was also evaluated (sppl. table 2). For SOD1 patients, LMN signs usually 
predominated. Most of the TARDBP patients initially presented with both UMN and LMN signs; with disease progression, LMN signs became predominant. One patient carrying the novel W385G mutation (exhibiting the longest survival time) developed final predominance of limb spasticity. FUS patients showed continuous predominance of LMN involvement except for the R521H patients with prolonged survival who developed marked UMN signs at onset. ANOVA tests used to compare mean bulbar scores between SOD1, TARDBP, FUS and other FALS groups showed a significant difference (table 2). Worsening of bulbar function with time tends to be less severe for the SODI and FUS groups compared to both TARDBP and other FALS patients (table 2).

No clinically-apparent frontotemporal dysfunction occurred in SOD1 patients (table 2). Two out of 10 patients with TARDBP mutations demonstrated cognitive impairment that met criteria for frontotemporal dementia (FTD). One with the G295S mutation had FTD two years before developing bulbar motor signs.[19] The other (with the novel G384R TARDBP mutation) developed FTD one year after the onset of motor weakness. A single patient carrying the R521H FUS mutation presented with cognitive impairment five months after the onset of ALS. The proportion of patients with cognitive impairment was not statistically different between the SOD1, TARDBP, FUS and other FALS patients (table 2).

\section{Discussion.}

This study represents the first large scale investigation of FALS among the French population and the first report comparing the phenotypes of the recently identified ALS genes. A mutation was identified in 36 out of the 162 tested families (22.2\%). The overall percentages of SOD1 (12.5\%), ANG (0.6\%), VAPB (0.6\%), TARDBP (4.3\%) and FUS (4.3\%) mutations were relatively close to those previously reported in European populations (sppl. table 1).

All of the 31 different mutations reported here affected evolutionarily conserved residues in the corresponding proteins and were absent from 500 controls (1000 chromosomes). The segregation with the disease could be established in 11 families (4 SOD1, 3 TARDBP and 4 FUS). The co-segregation of 11 TARDBP mutations [5, 6, 8, 9, $10,19,20,21,22,23]$ and 6 FUS mutations $[12,13,24,25]$ with ALS has been previously demonstrated. In this report, we extend these lists to include two new TARDBP mutations (G384R and W385G), two new FUS mutations (R521S and R521L) as well as the R514S FUS mutation. The extension of our pedigrees should allow confirming the segregation of the disease with these mutations. Indeed labeling a variant as pathogenic is a danger. We found two index cases harboring $A N G$ variants $(\mathrm{K} 54 \mathrm{E}$ and $\mathrm{R} 121 \mathrm{H})$ that did not segregate with disease and we concluded that 
they were not the cause of the disease in these FALS. Moreover we found a FUS mutation in two index cases harboring $A N G$ variants (K54E or K17I). These results suggest that, as for others,[26] the association of some $A N G$ variants and ALS is questionable.

Some of the mutations we identified demonstrated variable penetrance. For example, we confirmed the presence of TARDBP mutations in 2 obligate female carriers who transmitted the disease to their children but who were asymptomatic at age 65 and 73.

The number of patients allowed comparison of phenotypes in relation to the involved gene. Although these findings have to be confirmed in larger populations, we could find statistical differences for some clinical traits between the different mutation groups. Patients with SODI mutations usually first developed lower limb weakness whereas patients with TARDBP mutations had onset predominantly in the upper limbs. Patients harboring FUS mutations had various onset sites in the arms, legs or bulbar muscles, which more resembles to the typical ALS.

Evolution of the disease was categorized as rapid (<3 years), medium (3-7 years), or long ( 7 years) for each gene. FUS mutations seemed to lead to the most aggressive disease, with a young onset and a rapid course for most of the patients, an observation that is consistent with previous reports.[12, 13] Analyses also showed that life span is shortened for FUS patients. Among patients with FUS mutations, three with the R521H mutation had a disease course that was approximately 2-fold longer than the others (sppl. table 2). Our results also showed that bulbar deterioration and cognitive impairment tended to be less frequent in patients harboring SODI and FUS mutations.

Considerable intra-familial phenotypic differences were observed in some families carrying various mutations in the SOD1, TARDBP and FUS genes. Age and site of onset varied between members of a family. The disease duration could also differ, as shown in families carrying the D83G SOD1 mutation (6-151 months in 2 brothers with similar age at onset), the W385G TARDBP mutation, and the R521H FUS mutation. These data support the hypothesis that a mutation is not the only factor that determines the clinical course of the disease. Other factors must also contribute to phenotype, and it is not yet possible to predict the evolution of patients based solely on presence of the mutation or rate of progression in other family members.

Altogether our results show that one determinant of ALS phenotype is the underlying causative mutation. However heterogeneity between and among families implies that other environmental and genetic influences contribute to not only the rate of evolution and which signs predominate, but also whether the disease will appear at all during life. Despite recent advances in the field of ALS genetics, most of the genes involved in FALS are still unknown. Considerable work lies ahead in determining the genetic and environmental factors that most contribute to ALS. 


\section{Acknowledgments.}

We are grateful to the patients and their families. We thank Joelle Debusne, Eliane Gardais, Luzia Vacherie, Thierry Larmonier and Dr Safaa Saker (Genethon cell and DNA bank), and Christelle Dussert, Isabelle Lagroua, Sylvie Forlani and Dr Alexandra Dürr (CRICM DNA and cell bank) for patient DNA, Patricia Bouillon for searching archival documents and Elodie Chabrol for kind technical help. This study was supported by the Association pour la Recherche sur la sclérose latérale amyotrophique et autres maladies du motoneurone (ARS).

\section{Figure Legends}

figure 1. Distribution of each group of patients by age of onset, site of onset, disease duration and life span.

A. Histograms showing the distribution of patients with SOD1, TARDBP or FUS mutations and other FALS patients according to bulbar (black), upper limb (dark-grey) or lower limb (light grey) onset. B. Histograms illustrating the distribution of SOD1, TARDBP, FUS or other FALS patients by disease duration (in months): Black: <36 months, dark-grey: 36-84 months, light grey: >84 months. Cox regression curves of (C) cumulative probability of disease onset according to the age of patients, (D) cumulative survival probability according to the age of patients and (E) cumulative survival probability from time of disease onset. C-E. The four patient groups were SOD1 (grey thin line), TARDBP (grey bold line), FUS (black bold line) and other FALS (black thin line). The graph was truncated at 200 months in (E) to improve visualization at short time points. F. Kaplan-Meier plots of cumulative survival from time of disease onset of patients carrying different FUS mutations: either R521H (bold line) or other mutations combined (dotted line).

supplementary figure 1. SOD1, TARDBP and FUS mutations segregating with the disease. Pedigree of the F8S, F15S, F17S and F20S families with the D83G (A), G93V (B), N139D (C) and I151T (D) SOD1 mutation. Pedigree of the F28T, F29T and F25T families with the G384R (E), W385G (F) and G348C (G) TARDBP mutations. Pedigree of the F31F, F36F, F35F and F30F families with the R521S (H), R521L (I), R521H (J) and R514S (K) FUS mutations. Arrows indicate index patients. When available, the age at death and the disease duration (in brackets) are indicated above the symbol representing the patients. The genotypes are indicated using a single letter amino acid code below the index case and some relatives for whom DNA was available. 


\section{References}

1 Rosen DR. Mutations in $\mathrm{Cu} / \mathrm{Zn}$ superoxide dismutase gene are associated with familial amyotrophic lateral sclerosis. Nature 1993;364(6435):362.

2 Nishimura AL, Mitne-Neto M, Silva HC, et al. A mutation in the vesicle-trafficking protein VAPB causes late-onset spinal muscular atrophy and amyotrophic lateral sclerosis. Am J Hum Genet 2004;75(5):822-31.

3 Nishimura AL, Al-Chalabi A, Zatz M. A common founder for amyotrophic lateral sclerosis type 8 (ALS8) in the Brazilian population. Hum Genet 2005;118(3-4):499-500.

4 Greenway MJ, Andersen PM, Russ C, et al. ANG mutations segregate with familial and 'sporadic' amyotrophic lateral sclerosis. Nat Genet 2006;38(4):411-3.

5 Gitcho MA, Baloh RH, Chakraverty S, et al. TDP-43 A315T mutation in familial motor neuron disease. Ann Neurol 2008;63(4):535-8.

6 Kabashi E, Valdmanis PN, Dion P, et al. TARDBP mutations in individuals with sporadic and familial amyotrophic lateral sclerosis. Nat Genet 2008;40(5):572-4.

Rutherford NJ, Zhang YJ, Baker M, et al. Novel mutations in TARDBP (TDP-43) in patients with familial amyotrophic lateral sclerosis. PLoS Genet 2008;4(9):e1000193.

Sreedharan J, Blair IP, Tripathi VB, et al. TDP-43 mutations in familial and sporadic amyotrophic lateral sclerosis. Science 2008;319(5870):1668-72.

Van Deerlin VM, Leverenz JB, Bekris LM, et al. TARDBP mutations in amyotrophic lateral sclerosis with TDP-43 neuropathology: a genetic and histopathological analysis. Lancet Neurol 2008;7(5):409-16.

Yokoseki A, Shiga A, Tan CF, et al. TDP-43 mutation in familial amyotrophic lateral sclerosis. Ann Neurol 2008;63(4):538-42.

Kuhnlein P, Sperfeld AD, Vanmassenhove B, et al. Two German kindreds with familial amyotrophic lateral sclerosis due to TARDBP mutations. Arch Neurol 2008;65(9):1185-9.

Kwiatkowski TJ, Jr., Bosco DA, Leclerc AL, et al. Mutations in the FUS/TLS gene on chromosome 16 cause familial amyotrophic lateral sclerosis. Science 2009;323(5918):1205-8.

Vance C, Rogelj B, Hortobagyi T, et al. Mutations in FUS, an RNA processing protein, cause familial amyotrophic lateral sclerosis type 6. Science 2009;323(5918):1208-11.

Brooks BR, Miller RG, Swash M, et al. El Escorial revisited: revised criteria for the diagnosis of amyotrophic lateral sclerosis. Amyotroph Lateral Scler Other Motor Neuron Disord 2000;1(5):293-9.

Neary D, Snowden JS, Gustafson L, et al. Frontotemporal lobar degeneration: a consensus on clinical diagnostic criteria. Neurology 1998;51(6):1546-54.

Bensimon G, Lacomblez L, Meininger V. A controlled trial of riluzole in amyotrophic lateral sclerosis. ALS/Riluzole Study Group. N Engl J Med 1994;330(9):585-91.

Fernandez-Santiago R, Hoenig S, Lichtner P, et al. Identification of novel Angiogenin (ANG) gene missense variants in German patients with amyotrophic lateral sclerosis. J Neurol 2009;256(8):1337-42.

Paubel A, Violette J, Amy M, et al. Mutations of the ANG gene in French patients with sporadic amyotrophic lateral sclerosis. Arch Neurol 2008;65(10):1333-6.

Benajiba L, Le Ber I, Camuzat A, et al. TARDBP mutations in motoneuron disease with frontotemporal lobar degeneration. Ann Neurol 2009;65(4):470-3. mutations in amyotrophic lateral sclerosis. Neurogenetics. Published Online First: 17 september 2009. doi:10.1007/s10048-009-0218-9

A, Gellera C, et al. High frequency of TARDBP gene mutations in Italian patients with amyotrophic lateral sclerosis. Hum Mutat 2009;30(4):688-94.

Del Bo R, Ghezzi S, Corti S, et al. TARDBP (TDP-43) sequence analysis in patients with familial and sporadic ALS: identification of two novel mutations. Eur J Neurol 2009;16(6):727-32.

Origone P, Caponnetto C, Bandettini di Poggio M, et al. Enlarging clinical spectrum of FALS with TARDBP gene mutations: S393L variant in an Italian family showing phenotypic variability and relevance for genetic counselling. Amyotroph Lateral Scler 2009:1-5.

Corrado L, Battistini S, Penco S, et al. Variations in the coding and regulatory sequences of the angiogenin (ANG) gene are not associated to ALS (amyotrophic lateral sclerosis) in the Italian population. J Neurol Sci 2007;258(1-2):123-7. Boukaftane Y, Khoris J, Moulard B, et al. Identification of six novel SOD1 gene mutations in familial amyotrophic lateral sclerosis. Can J Neurol Sci 1998;25(3):192-6.

Shaw CE, Enayat ZE, Chioza BA, et al. Mutations in all five exons of SOD-1 may cause ALS. Ann Neurol 1998;43(3):390-4.

Deng HX, Tainer JA, Mitsumoto H, et al. Two novel SOD1 mutations in patients with familial amyotrophic lateral sclerosis. Hum Mol Genet 1995;4(6):1113-6.

Maeda T, Kurahashi K, Matsunaga M, et al. [On intra-familial clinical diversities of a familial amyotrophic lateral sclerosis with a point mutation of Cu/Zn superoxide dismutase (Asn 86-Ser]. No To Shinkei 1997;49(9):847-51.

Esteban J, Rosen DR, Bowling AC, et al. Identification of two novel mutations and a new polymorphism in the gene for $\mathrm{Cu} / \mathrm{Zn}$ superoxide dismutase in patients with amyotrophic lateral sclerosis. Hum Mol Genet 1994;3(6):997-8. 
Hosler BA, Nicholson GA, Sapp PC, et al. Three novel mutations and two variants in the gene for Cu/Zn superoxide dismutase in familial amyotrophic lateral sclerosis. Neuromuscul Disord 1996;6(5):361-6.

Andersen PM, Sims KB, Xin WW, et al. Sixteen novel mutations in the $\mathrm{Cu} / \mathrm{Zn}$ superoxide dismutase gene in amyotrophic lateral sclerosis: a decade of discoveries, defects and disputes. Amyotroph Lateral Scler Other Motor Neuron Disord 2003;4(2):62-73.

Andersen PM. Amyotrophic Lateral Sclerosis genetics with Mendelian inheritance. In: Brown RH, Swash M, Pasinelli P, eds. Amyotrophic Lateral Sclerosis, 2 ed: Informa healthcare 2006:187-207.

Kostrzewa M, Damian MS, Muller U. Superoxide dismutase 1: identification of a novel mutation in a case of familial amyotrophic lateral sclerosis. Hum Genet 1996;98(1):48-50.

Abe K, Aoki M, Ikeda M, et al. Clinical characteristics of familial amyotrophic lateral sclerosis with Cu/Zn superoxide dismutase gene mutations. J Neurol Sci 1996;136(1-2):108-16.

Aguirre T, Matthijs G, Robberecht W, et al. Mutational analysis of the $\mathrm{Cu} / \mathrm{Zn}$ superoxide dismutase gene in 23 familial and 69 sporadic cases of amyotrophic lateral sclerosis in Belgium. Eur J Hum Genet 1999;7(5):599-602.

Jones CT, Swingler RJ, Simpson SA, et al. Superoxide dismutase mutations in an unselected cohort of Scottish amyotrophic lateral sclerosis patients. J Med Genet 1995;32(4):290-2.

Andersen PM, Nilsson P, Keranen ML, et al. Phenotypic heterogeneity in motor neuron disease patients with CuZnsuperoxide dismutase mutations in Scandinavia. Brain 1997;120 ( Pt 10):1723-37.

Cudkowicz ME, McKenna-Yasek D, Sapp PE, et al. Epidemiology of mutations in superoxide dismutase in amyotrophic lateral sclerosis. Ann Neurol 1997;41(2):210-21.

Orrell RW, Marklund SL, deBelleroche JS. Familial ALS is associated with mutations in all exons of SOD1: a novel mutation in exon 3 (Gly72Ser). J Neurol Sci 1997;153(1):46-9.

Garcia-Redondo A, Bustos F, Juan YSB, et al. Molecular analysis of the superoxide dismutase 1 gene in Spanish patients with sporadic or familial amyotrophic lateral sclerosis. Muscle Nerve 2002;26(2):274-8.

Battistini S, Giannini F, Greco G, et al. SOD1 mutations in amyotrophic lateral sclerosis. Results from a multicenter Italian study. J Neurol 2005;252(7):782-8.

Gamez J, Corbera-Bellalta M, Nogales G, et al. Mutational analysis of the $\mathrm{Cu} / \mathrm{Zn}$ superoxide dismutase gene in a Catalan ALS population: should all sporadic ALS cases also be screened for SOD1? J Neurol Sci 2006;247(1):21-8.

Gellera C, Castellotti B, Riggio MC, et al. Superoxide dismutase gene mutations in Italian patients with familial and sporadic amyotrophic lateral sclerosis: identification of three novel missense mutations. Neuromuscul Disord 2001;11(4):404-10.

Niemann S, Joos H, Meyer T, et al. Familial ALS in Germany: origin of the R115G SOD1 mutation by a founder effect. J Neurol Neurosurg Psychiatry 2004;75(8):1186-8.

van Es MA, Diekstra FP, Veldink JH, et al. A case of ALS-FTD in a large FALS pedigree with a K17I ANG mutation. Neurology 2009;72(3):287-8.

Gellera C, Colombrita C, Ticozzi N, et al. Identification of new ANG gene mutations in a large cohort of Italian patients with amyotrophic lateral sclerosis. Neurogenetics 2008;9(1):33-40.

Conforti FL, Sprovieri T, Mazzei R, et al. A novel Angiogenin gene mutation in a sporadic patient with amyotrophic lateral sclerosis from southern Italy. Neuromuscul Disord 2008;18(1):68-70. Landers JE, Leclerc AL, Shi L,
Neurology 2008;70(14):1179-85.

Kirby J, Hewamadduma CA, Hartley JA, et al. Mutations in VAPB are not associated with sporadic ALS. Neurology 2007;68(22):1951-3.

Kamada M, Maruyama H, Tanaka E, et al. Screening for TARDBP mutations in Japanese familial amyotrophic lateral sclerosis. J Neurol Sci 2009;284(1-2):69-71.

Damme PV, Goris A, Race V, et al. The occurrence of mutations in FUS in a Belgian cohort of patients with familial ALS. Eur J Neurol. Published Online First: 18 November 2009. doi:10.1111/j.1468-1331.2009.02859

Chio A, Restagno G, Brunetti M, et al. Two Italian kindreds with familial amyotrophic lateral sclerosis due to FUS mutation. Neurobiol Aging 2009;30(8):1272-5.

Blair IP, Williams KL, Warraich ST, et al. FUS mutations in amyotrophic lateral sclerosis: clinical, pathological, neurophysiological and genetic analysis. J Neurol Neurosurg Psychiatry. Published Online First: 3 December 2009. doi:10.1136/jnnp.2009.194399

Belzil VV, Valdmanis PN, Dion PA, et al. Mutations in FUS cause FALS and SALS in French and French Canadian populations. Neurology 2009;73(15):1176-9.

Drepper C, Herrmann T, Wessig C, et al. C-terminal FUS/TLS mutations in familial and sporadic ALS in Germany. Neurobiol Aging. Published Online First: 16 december 2009. doi:10.1016/j.neurobiolaging.2009.11.017 


\begin{tabular}{|c|c|c|c|c|c|c|}
\hline Genes & $\begin{array}{l}\text { Family } \\
\text { number }\end{array}$ & $\begin{array}{l}\text { Nucleotide } \\
\text { change }^{*}\end{array}$ & $\begin{array}{l}\text { Amino acid } \\
\text { change } \\
\text { (HGVS) }\end{array}$ & $\begin{array}{l}\text { Amino acid } \\
\text { change } \mathrm{e}^{* * * *}\end{array}$ & Exon & $\begin{array}{l}\text { First description } \\
\text { of the mutation }\end{array}$ \\
\hline \multirow[t]{20}{*}{ SOD1 } & F1S & c. $65 \mathrm{~A}>\mathrm{G}$ & p.Glu22Gly & E21G & 1 & [25] \\
\hline & $\mathrm{F} 2 \mathrm{~S}$ & c. $112 \mathrm{G}>\mathrm{A}$ & p.Gly38Arg & G37R & 2 & [1] \\
\hline & F3S & c. $116 \mathrm{~T}>\mathrm{G}$ & p.Leu39Arg & L38R & 2 & [25] \\
\hline & $\mathrm{F} 4 \mathrm{~S}$ & c. $124 \mathrm{G}>\mathrm{A}$ & p.Gly42Ser & G41S & 2 & [1] \\
\hline & F5S & c. $124 \mathrm{G}>\mathrm{A}$ & p.Gly42Ser & G41S & 2 & [1] \\
\hline & F6S & c. $139 \mathrm{C}>\mathrm{G}$ & p.His47Asp & H46D & 2 & this report \\
\hline & F7S & c. $200 \mathrm{C}>\mathrm{G}$ & p.Pro67Arg & P66R & 3 & this report \\
\hline & F8S & c. $251 \mathrm{~A}>\mathrm{G}$ & p.Asp84Gly & D83G & 4 & this report \\
\hline & F9S & c. $255 \mathrm{G}>\mathrm{C}$ & p.Leu85Phe & $\mathrm{L} 84 \mathrm{~F}$ & 4 & {$[25,26]$} \\
\hline & F10S & c. $253 \mathrm{~T}>\mathrm{G}$ & p.Leu85Val & L84V & 4 & [27] \\
\hline & F11S & c. $260 A>G$ & p.Asn87Ser & N86S & 4 & {$[28]$} \\
\hline & F12S & c. $280 \mathrm{G}>\mathrm{T}$ & p.Gly94Cys & G93C & 4 & {$[1]$} \\
\hline & F13S & c. $281 \mathrm{G}>\mathrm{C}$ & p.Gly94Ala & G93A & 4 & [1] \\
\hline & F14S & c. $281 \mathrm{G}>\mathrm{A}$ & pGly94Asp & G93D & 4 & [29] \\
\hline & F15S & c. $281 \mathrm{G}>\mathrm{T}$ & p.Gly94Val & G93V & 4 & [30] \\
\hline & F16S & c. $355 \mathrm{G}>\mathrm{C}$ & p.Val119Leu & V118L & 4 & [31] \\
\hline & F17S & c. $418 \mathrm{~A}>\mathrm{G}$ & p.Asn140Asp & N139D & 5 & {$[32]$} \\
\hline & F18S & c. $443 \mathrm{G}>\mathrm{A}$ & p.Gly148Asp & G147D & 5 & {$[32]$} \\
\hline & F19S & c. $443 \mathrm{G}>\mathrm{A}$ & p.Gly148Asp & G147D & 5 & [32] \\
\hline & F20S & c. $455 \mathrm{~T}>\mathrm{C}$ & p.Ile152Thr & $\mathrm{I} 151 \mathrm{~T}$ & 5 & [33] \\
\hline$A N G$ & F21A & c. $122 \mathrm{~A}>\mathrm{T}$ & p.Lys41Ile & K17I & 1 & [4] \\
\hline$V A P B$ & $\mathrm{~F} 22 \mathrm{~V}$ & c. $166 \mathrm{C}>\mathrm{T}$ & p.Pro56Ser & P56S & 2 & [2] \\
\hline \multirow[t]{7}{*}{$T A R D B P$} & F23T & c. $883 \mathrm{G}>\mathrm{A}$ & p.Gly295Ser & G295S & 6 & {$[19,21]$} \\
\hline & $\mathrm{F} 24 \mathrm{~T}$ & c. $943 \mathrm{G}>\mathrm{A}$ & p.Ala315Thr & $\mathrm{A} 315 \mathrm{~T}$ & 6 & {$[6]$} \\
\hline & $\mathrm{F} 25 \mathrm{~T}$ & c. $1042 \mathrm{G}>\mathrm{T}$ & p.Gly348Cys & G348C & 6 & {$[6]$} \\
\hline & F26T & c. $1144 \mathrm{G}>\mathrm{A}$ & p.Ala382Thr & $\mathrm{A} 382 \mathrm{~T}$ & 6 & [6] \\
\hline & $\mathrm{F} 27 \mathrm{~T}$ & c. $1144 \mathrm{G}>\mathrm{A}$ & p.Ala382Thr & $\mathrm{A} 382 \mathrm{~T}$ & 6 & [6] \\
\hline & $\mathrm{F} 28 \mathrm{~T}$ & c. $1150 \mathrm{G}>\mathrm{C}$ & p.Gly384Arg & G384R & 6 & this report \\
\hline & $\mathrm{F} 29 \mathrm{~T}$ & c. $1153 \mathrm{~T}>\mathrm{G}$ & p.Trp385Gly & W385G & 6 & this report \\
\hline \multirow[t]{7}{*}{ FUS } & F30F & c. $1542 \mathrm{G}>\mathrm{T}$ & p.Arg514Ser & R514S & 15 & [12] \\
\hline & $\mathrm{F} 31 \mathrm{~F}^{(1)}$ & c. $1561 \mathrm{C}>\mathrm{A}$ & p.Arg521Ser & R521S & 15 & this report \\
\hline & $\mathrm{F} 32 \mathrm{~F}$ & c. $1561 \mathrm{C}>\mathrm{T}$ & p.Arg521Cys & R521C & 15 & {$[12,13]$} \\
\hline & $\mathrm{F} 33 \mathrm{~F}^{(2)}$ & c. $1561 \mathrm{C}>\mathrm{T}$ & p.Arg521Cys & $\mathrm{R} 521 \mathrm{C}$ & 15 & {$[12,13]$} \\
\hline & F34F & c. $1561 \mathrm{C}>\mathrm{T}$ & p.Arg521Cys & $\mathrm{R} 521 \mathrm{C}$ & 15 & {$[12,13]$} \\
\hline & $\mathrm{F} 35 \mathrm{~F}$ & c. $1562 \mathrm{G}>\mathrm{A}$ & p.Arg521His & $\mathrm{R} 521 \mathrm{H}$ & 15 & {$[12,13]$} \\
\hline & F36F & c. $1562 \mathrm{G}>\mathrm{T}$ & p.Arg521Leu & $\mathrm{R} 521 \mathrm{~L}$ & 15 & this report \\
\hline
\end{tabular}

Millecamps et al. 


\begin{tabular}{lllll} 
Patient groups & SOD1 & TARDBP & FUS & other FALS \\
\hline M:F ratio & $1.2: 1(\mathrm{n}=55)$ & $1: 1.87(\mathrm{n}=23)$ & $1.23: 1(\mathrm{n}=29)$ & $2: 1(\mathrm{n}=126)$ \\
\hline Age at Onset (years) & $55(\mathrm{SE} 2, \mathrm{n}=38)$ & $54(\mathrm{SE} 4, \mathrm{n}=17)$ & $45(\mathrm{SE} 3, \mathrm{n}=23)$ & $58(\mathrm{SE} 1, \mathrm{n}=115)$ \\
Mean (SE) & $55(\mathrm{SE} 2, \mathrm{n}=38)$ & $58(\mathrm{SE} 5, \mathrm{n}=17)$ & $47(\mathrm{SE} 7, \mathrm{n}=23)$ & $58(\mathrm{SE} 2, \mathrm{n}=115)$ \\
\cline { 2 - 4 } & & $\mathrm{n}=0.004$
\end{tabular}

\begin{tabular}{|c|c|c|c|c|}
\hline \multicolumn{5}{|c|}{ Disease duration (months) $^{* *}$} \\
\hline Mean (SE) & $79(\mathrm{SE} 14, \mathrm{n}=38)$ & $58(\operatorname{SE} 9, \mathrm{n}=17)$ & $30(\mathrm{SE} 4, \mathrm{n}=23)$ & $45(\mathrm{SE} 5, \mathrm{n}=100)$ \\
\hline Median (SE) & $36(\mathrm{SE} 10, \mathrm{n}=38)$ & $51(\operatorname{SE} 9, \mathrm{n}=17)$ & $26(\mathrm{SE} 3, \mathrm{n}=23)$ & $32(\mathrm{SE} 2, \mathrm{n}=100)$ \\
\hline Cox regression test ${ }^{*}$ & \multicolumn{4}{|c|}{$\mathrm{p}=0.005$} \\
\hline
\end{tabular}

\begin{tabular}{|c|c|c|c|c|}
\hline \multicolumn{5}{|l|}{ Life span (years) ${ }^{* *}$} \\
\hline Mean (SE) & $59(\operatorname{SE} 2, \mathrm{n}=45)$ & $59(\operatorname{SE} 4, \mathrm{n}=21)$ & $46(\operatorname{SE~} 2, \mathrm{n}=29)$ & $61(\mathrm{SE} 1, \mathrm{n}=101)$ \\
\hline Median (SE) & $59(\operatorname{SE~} 2, \mathrm{n}=45)$ & $60(\operatorname{SE~} 5, \mathrm{n}=21)$ & $45(\operatorname{SE~} 6, \mathrm{n}=29)$ & $59(\mathrm{SE} 2, \mathrm{n}=101$ \\
\hline Cox regression test ${ }^{*}$ & \multicolumn{4}{|c|}{$\mathrm{p}<0.0001$} \\
\hline Mean bulbar score ${ }^{* * *}$ & $3.7(\mathrm{SE} 1, \mathrm{n}=13)$ & $11.7(\mathrm{SE} 3.2, \mathrm{n}=7)$ & $3.6($ SE $0.7, n=9)$ & $9.3(\mathrm{SE} 1.4, \mathrm{n}=50)$ \\
\hline ANOVA & \multicolumn{4}{|c|}{$\mathrm{p}=0.0454$} \\
\hline Cognitive impairments $^{* * * *}$ & $0 / 20$ & $2 / 10$ & $1 / 13$ & $10 / 62$ \\
\hline
\end{tabular}

\section{table 2. Disease characteristics by mutated gene.}

$\mathrm{SE}=$ standard error. $\mathrm{n}=$ number of patients for whom the information was available. NA=data not available. *: equality of survival distribution between $S O D 1, T A R D B P$ and $F U S$ groups was analyzed using a Log Rank test. If the difference was significant $\mathrm{p}<0.05$, the groups were compared by pairs using a Log rank test. *** disease duration and age at death data included censored data ( 8 for $S O D 1,2$ for TARDBP and 1 for $F U S)^{* * *}$ : The difference between initial (at onset) and final (at the end of the disease) bulbar Norris scale (13 items) was recorded for each patient. Means were compared using one way ANOVA. ${ }^{* * * *}:$ the fraction represents the number of patients with cognitive impairment / the total number of patients who were examined for cognitive deficits. 
A

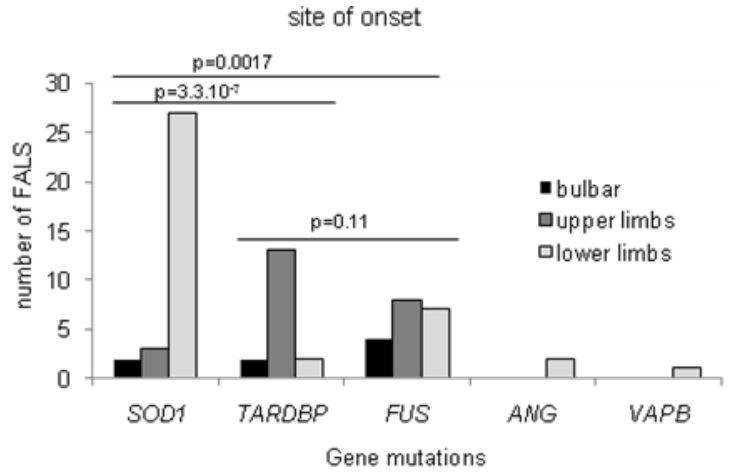

B

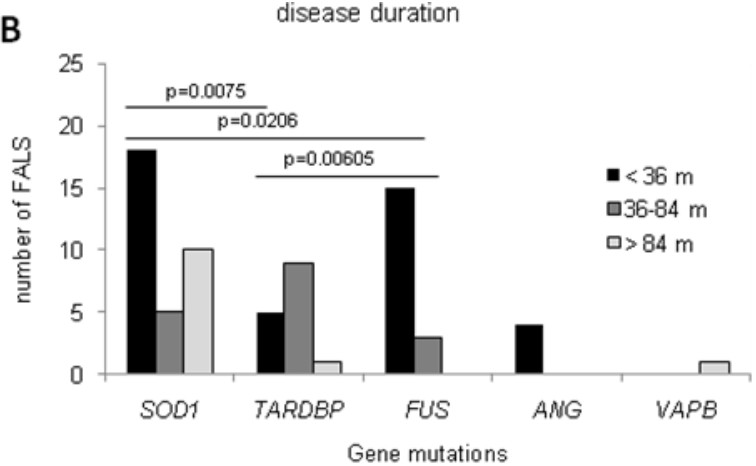

E

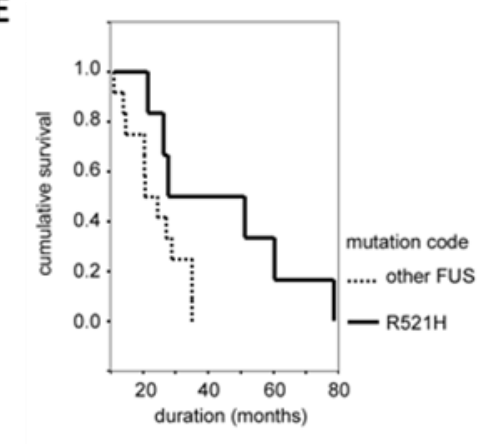

disease duration
$36-84 \mathrm{~m}$

$>84 \mathrm{~m}$

Gene mutations
C

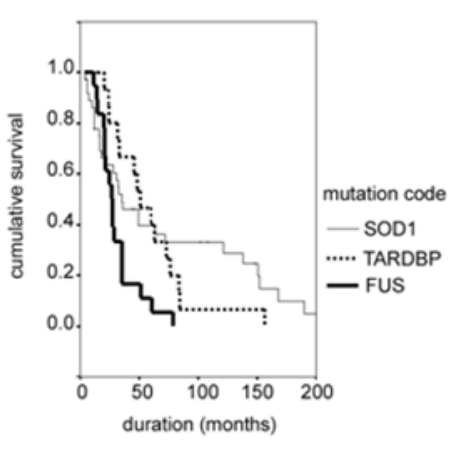

D

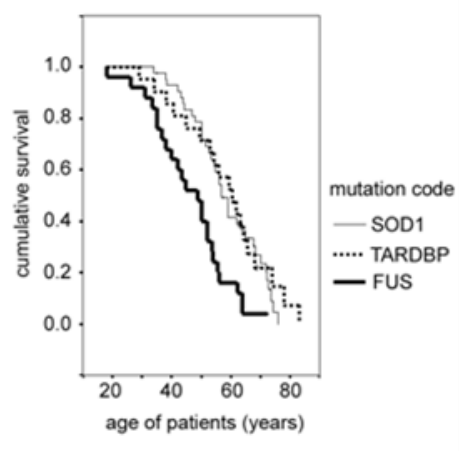

Millecamps et al.

figure 1. Distribution of each group of mutated patients by site of onset, disease duration and life span. A. Histograms showing the distribution of patients with SOD1, TARDBP, FUS, ANG or VAPB mutations according to bulbar (black), upper limb (dark-gray) or lower limb (light gray) onset. B. Histograms illustrating the distribution of $S O D 1, T A R D B P, F U S, A N G$ or VAPB mutated patients by disease duration (in months): Black: <3 years, dark-gray: 37 years, light gray: $>7$ years. C. Kaplan-Meier plots of cumulative survival from time of disease onset for SODl (thin line), TARDBP (dotted line) and FUS (bold line) patients. The graph was truncated at 200 months to improve visualization at short time points. D. Survival probability for SODI (thin line), TARDBP (dotted line) and FUS (bold line) mutated patients according to the age of patients (life span). E. Survival probability of patients carrying different FUS mutations: either R521H (bold line) or other mutations combined (dotted line). A Fisher's exact test compared group distributions by pairs (A-B). 
Millecamps et al. J. Med Genet 2010

Accepted Manuscript

\begin{tabular}{|c|c|c|c|c|c|c|c|c|}
\hline \multirow[b]{2}{*}{ Gene } & \multirow{2}{*}{$\begin{array}{l}\text { mutational } \\
\text { frequency } \\
(\%)\end{array}$} & \multirow{2}{*}{$\begin{array}{l}\text { nb mutated } \\
/ \text { nb studied }\end{array}$} & \multicolumn{4}{|c|}{ population tested for: } & \multirow[b]{2}{*}{ origin of population } & \multirow[b]{2}{*}{ references } \\
\hline & & & SOD1 & $A N G$ & $V A P B$ & $T A R D B P$ & & \\
\hline \multirow[t]{14}{*}{ SOD1 } & 71.4 & $5 / 7$ & - & - & - & - & Japan & {$[34]$} \\
\hline & 63.6 & $7 / 11$ & - & - & - & - & Belgium & [35] \\
\hline & 50.0 & $5 / 10$ & - & - & - & - & Scotland & {$[36]$} \\
\hline & 23.5 & $12 / 51$ & - & - & - & - & Scandinavia & [37] \\
\hline & 23.4 & $68 / 290$ & - & - & - & - & USA & {$[38]$} \\
\hline & 21.1 & $8 / 38$ & - & - & - & - & England & {$[26]$} \\
\hline & 19.7 & $14 / 71$ & - & - & - & - & England & [39] \\
\hline & 18.2 & $2 / 11$ & - & - & - & - & Spain & [40] \\
\hline & 17.9 & $7 / 39$ & - & - & - & - & Italy & [41] \\
\hline & 16.7 & $5 / 30$ & - & - & - & - & Catalonia & {$[42]$} \\
\hline & 14.7 & $5 / 34$ & - & - & - & - & Italy & [43] \\
\hline & 14.3 & $10 / 70$ & - & - & - & - & France & {$[25]$} \\
\hline & 12.3 & $20 / 162$ & & & & & France & This series \\
\hline & 12.0 & $9 / 75$ & - & - & - & - & Germany & {$[44]$} \\
\hline Total & 19.7 & $177 / 897$ & - & - & - & - & & \\
\hline \multirow[t]{7}{*}{$A N G$} & 2.6 & $1 / 39$ & + & - & - & - & Netherlands & {$[45]$} \\
\hline & 2.3 & $3 / 132$ & + & - & - & - & $\begin{array}{l}\text { Italy } \\
\text { Ireland, Scottland, }\end{array}$ & [46] \\
\hline & 1.7 & $3 / 176$ & + & - & - & - & Sweden, England & {$[4]$} \\
\hline & 0.7 & $1 / 142$ & + & - & - & - & France & This series \\
\hline & 0.0 & $0 / 83$ & + & - & - & - & USA & {$[4]$} \\
\hline & 0.0 & $0 / 12$ & + & - & - & - & Italy & {$[24]$} \\
\hline & 0.0 & $0 / 8$ & - & - & - & - & Italy & [47] \\
\hline Total & 1.5 & $10 / 589$ & + & - & - & - & & \\
\hline \multirow[t]{3}{*}{$V A P B$} & 1.3 & $1 / 80$ & - & - & - & - & USA(Brazilian) & {$[48]$} \\
\hline & 0.7 & $1 / 141$ & + & + & - & - & France(Japanese) & This series \\
\hline & 0.0 & $0 / 23$ & + & - & - & - & England & [49] \\
\hline Total & 0.8 & $2 / 252$ & + & - & - & - & & \\
\hline \multirow[t]{12}{*}{ TARDBP } & 18.8 & $3 / 16$ & + & + & + & - & Italy & {$[22]$} \\
\hline & 12.5 & $1 / 8$ & + & - & - & - & Europe & {$[5]$} \\
\hline & 6.5 & $2 / 31$ & + & - & - & - & Germany & [11] \\
\hline & 6.3 & $1 / 16$ & + & - & - & - & Japan & [10] \\
\hline & 5.0 & $7 / 140$ & + & + & + & - & France & This series \\
\hline & 5.0 & $4 / 80$ & + & + & + & - & France Québec & {$[6]$} \\
\hline & 4.8 & $2 / 42$ & + & - & - & - & Northern England & {$[20]$} \\
\hline & 4.8 & $6 / 125$ & + & + & - & - & Italy & {$[21]$} \\
\hline & 3.3 & $3 / 92$ & - & - & - & - & USA & [7] \\
\hline & 3.3 & $1 / 30$ & - & - & - & - & Japan & {$[50]$} \\
\hline & 3.1 & $2 / 65$ & + & - & - & - & USA & [9] \\
\hline & 0.6 & $1 / 154$ & + & + & + & - & England & {$[8]$} \\
\hline Total : & 4.1 & $33 / 796$ & + & + & + & - & & \\
\hline \multirow[t]{8}{*}{ FUS } & 5.8 & $17 / 292$ & - & - & - & - & USA & {$[12]$} \\
\hline & 5.3 & $7 / 133$ & + & + & + & + & France & This series \\
\hline & 4.5 & $1 / 22$ & + & + & + & + & Belgium & {$[51]$} \\
\hline & 4.0 & $8 / 199$ & + & + & + & + & England & [13] \\
\hline & 3.8 & $2 / 52$ & + & - & - & + & Italy & {$[52]$} \\
\hline & 3.2 & $4 / 124$ & + & + & + & + & Australia & [53] \\
\hline & 2.5 & $2 / 80$ & + & + & + & + & France Québec & [54] \\
\hline & 2.4 & $1 / 41$ & - & - & - & - & Germany & {$[55]$} \\
\hline Total : & 4.2 & $40 / 940$ & + & + & + & + & & \\
\hline
\end{tabular}

Supplementary table 1. Frequency of SOD1, ANG, VAPB, TARDBP and FUS mutations in FALS of various geographic origins. Data from this study is on grey background. To compare our data to other studies, frequencies we 
found were expressed in populations negative for previously tested genes. +: the corresponding gene has been analyzed in the population (mutated patients have been excluded from this sample). -: the corresponding gene has not been screened in the population or information is not available in the paper.

\section{Supplementary references for the sppl. table 1:}

Abe K, Aoki M, Ikeda M, et al. Clinical characteristics of familial amyotrophic lateral sclerosis with $\mathrm{Cu} / \mathrm{Zn}$ superoxide dismutase gene mutations. J Neurol Sci 1996;136(1-2):108-16.

Aguirre T, Matthijs G, Robberecht W, et al. Mutational analysis of the $\mathrm{Cu} / \mathrm{Zn}$ superoxide dismutase gene in 23 familial and 69 sporadic cases of amyotrophic lateral sclerosis in Belgium. Eur J Hum Genet 1999;7(5):599-602.

Jones CT, Swingler RJ, Simpson SA, et al. Superoxide dismutase mutations in an unselected cohort of Scottish amyotrophic lateral sclerosis patients. J Med Genet 1995;32(4):290-2.

Andersen PM, Nilsson P, Keranen ML, et al. Phenotypic heterogeneity in motor neuron disease patients with CuZnsuperoxide dismutase mutations in Scandinavia. Brain 1997;120 ( Pt 10):1723-37.

Cudkowicz ME, McKenna-Yasek D, Sapp PE, et al. Epidemiology of mutations in superoxide dismutase in amyotrophic lateral sclerosis. Ann Neurol 1997;41(2):210-21.

Orrell RW, Marklund SL, deBelleroche JS. Familial ALS is associated with mutations in all exons of SOD1: a novel mutation in exon 3 (Gly72Ser). J Neurol Sci 1997;153(1):46-9.

Garcia-Redondo A, Bustos F, Juan YSB, et al. Molecular analysis of the superoxide dismutase 1 gene in Spanish patients with sporadic or familial amyotrophic lateral sclerosis. Muscle Nerve 2002;26(2):274-8.

Battistini S, Giannini F, Greco G, et al. SOD1 mutations in amyotrophic lateral sclerosis. Results from a multicenter Italian study. J Neurol 2005;252(7):782-8.

Gamez J, Corbera-Bellalta M, Nogales G, et al. Mutational analysis of the Cu/Zn superoxide dismutase gene in a Catalan ALS population: should all sporadic ALS cases also be screened for SOD1? J Neurol Sci 2006;247(1):21-8.

Gellera C, Castellotti B, Riggio MC, et al. Superoxide dismutase gene mutations in Italian patients with familial and sporadic amyotrophic lateral sclerosis: identification of three novel missense mutations. Neuromuscul Disord 2001;11(4):404-10.

Niemann S, Joos H, Meyer T, et al. Familial ALS in Germany: origin of the R115G SOD1 mutation by a founder effect. J Neurol Neurosurg Psychiatry 2004;75(8):1186-8.

van Es MA, Diekstra FP, Veldink JH, et al. A case of ALS-FTD in a large FALS pedigree with a K17I ANG mutation. Neurology 2009;72(3):287-8.

Gellera C, Colombrita C, Ticozzi N, et al. Identification of new ANG gene mutations in a large cohort of Italian patients with amyotrophic lateral sclerosis. Neurogenetics 2008;9(1):33-40.

Conforti FL, Sprovieri T, Mazzei R, et al. A novel Angiogenin gene mutation in a sporadic patient with amyotrophic lateral sclerosis from southern Italy. Neuromuscul Disord 2008;18(1):68-70.

Landers JE, Leclerc AL, Shi L, et al. New VAPB deletion variant and exclusion of VAPB mutations in familial ALS. Neurology 2008;70(14):1179-85.

Kirby J, Hewamadduma CA, Hartley JA, et al. Mutations in VAPB are not associated with sporadic ALS. Neurology 2007;68(22):1951-3.

Kamada M, Maruyama H, Tanaka E, et al. Screening for TARDBP mutations in Japanese familial amyotrophic lateral sclerosis. J Neurol Sci 2009;284(1-2):69-71.

Chio A, Restagno G, Brunetti M, et al. Two Italian kindreds with familial amyotrophic lateral sclerosis due to FUS mutation. Neurobiol Aging 2009;30(8):1272-5.

Belzil VV, Valdmanis PN, Dion PA, et al. Mutations in FUS cause FALS and SALS in French and French Canadian populations. Neurology 2009;73(15):1176-9.

Drepper C, Herrmann T, Wessig C, et al. C-terminal FUS/TLS mutations in familial and sporadic ALS in Germany. Neurobiol Aging. Published Online First: 16 december 2009. doi:10.1016/j.neurobiolaging.2009.11.017. 


\begin{tabular}{|c|c|c|c|c|c|c|c|c|c|c|c|c|c|c|c|c|c|}
\hline Gene & 兽 & 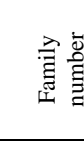 & 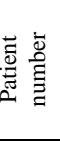 & 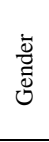 & 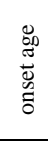 & & site at onset & initial & signs & $\begin{array}{l}\text { final } \\
\text { UL }\end{array}$ & $\begin{array}{l}\text { signs } \\
\text { LL }\end{array}$ & 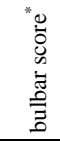 & $\begin{array}{c}\text { cognitive } \\
\text { impairment }\end{array}$ & 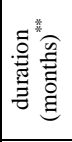 & 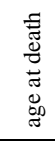 & 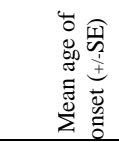 & 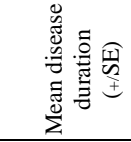 \\
\hline \multirow{35}{*}{ SOD1 } & E21G & F1S & 01 & $\mathrm{M}$ & 40 & LL & (dist) & $\mathrm{L}>\mathrm{U}$ & $\mathrm{L}>\mathrm{U}$ & $\mathrm{L}>\mathrm{U}$ & $\mathrm{L}>\mathrm{U}$ & 8 & no & 138 & 51 & 40 & 138 \\
\hline & G37R & F2S & 01 & $\mathrm{M}$ & 21 & LL & (dist) & $\mathrm{L}=\mathrm{U}$ & $\mathrm{L}=\mathrm{U}$ & & & & no & $>104$ & & & \\
\hline & & & 02 & $\mathrm{~F}$ & 28 & NA & & $\mathrm{L}=\mathrm{U}$ & $\mathrm{L}>\mathrm{U}$ & NA & NA & NA & NA & 121 & 37 & & \\
\hline & & & 03 & $\mathrm{~F}$ & 37 & LL & & $\mathrm{L}=\mathrm{U}$ & $\mathrm{L}=\mathrm{U}$ & NA & NA & NA & NA & 152 & 50 & & \\
\hline & & & 04 & $\mathrm{M}$ & 41 & NA & & $\mathrm{NA}$ & NA & NA & $\mathrm{NA}$ & NA & $\mathrm{NA}$ & 168 & 55 & $32(+/-5)$ & $147(+/-14)$ \\
\hline & L38R & F3S & 01 & $\mathrm{~F}$ & 51 & \begin{tabular}{|l|} 
LL \\
\end{tabular} & (prox) & $\mathrm{L}=\mathrm{U}$ & $\mathrm{L}=\mathrm{U}$ & $\mathrm{L}=\mathrm{U}$ & $\mathrm{L}=\mathrm{U}$ & 3 & no & 33 & 53 & 51 & 33 \\
\hline & G41S & F4S & 01 & $\mathrm{~F}$ & 51 & LL & (dist) & $\mathrm{L}=\mathrm{U}$ & $\mathrm{L} \gg \mathrm{U}$ & $\mathrm{L} \gg \mathrm{U}$ & $\mathrm{L} \gg>\mathrm{U}$ & 0 & no & 16 & 53 & & \\
\hline & & & 02 & $\mathrm{~F}$ & 69 & LL & (dist) & NA & NA & $\mathrm{NA}$ & NA & NA & NA & 12 & 70 & & \\
\hline & & & 03 & M & 50 & LL & & $\mathrm{L}=\mathrm{U}$ & $\mathrm{L}=\mathrm{U}$ & $\mathrm{L}>\mathrm{U}$ & $\mathrm{L}>\mathrm{U}$ & NA & NA & 16 & 50 & & \\
\hline & & F5S & 01 & $\mathrm{~F}$ & 60 & UL & (prox) & NA & NA & NA & NA & NA & NA & 28 & 62 & & \\
\hline & & & 02 & $\mathrm{~F}$ & 42 & LL & & NA & NA & NA & NA & NA & NA & 12 & 43 & $54(+/-5)$ & $17(+1-3)$ \\
\hline & H46D & F6S & 01 & $\mathrm{~F}$ & 53 & B & (dysphonia, dysphagia) & $\mathrm{L}=\mathrm{U}$ & $\mathrm{L}>\mathrm{U}$ & $\mathrm{L}=\mathrm{U}$ & $\mathrm{L}>\mathrm{U}$ & 6 & no & 17 & 54 & 53 & 17 \\
\hline & P66R & F7S & 01 & $\mathrm{~F}$ & 38 & LL & (dist) & $\mathrm{L}>\mathrm{U}$ & $\mathrm{L}>\mathrm{U}$ & $\mathrm{L}>\mathrm{U}$ & $\mathrm{L}>\mathrm{U}$ & & & $>355$ & & 38 & \\
\hline & D83G & F8S & 01 & $\mathrm{~F}$ & 55 & LL & (dist) & $\mathrm{L}>\mathrm{U}$ & $\mathrm{L}>\mathrm{U}$ & $\mathrm{L}>\mathrm{U}$ & $\mathrm{L}>\mathrm{U}$ & 1 & no & 151 & 68 & & \\
\hline & & & 02 & $\mathrm{M}$ & 72 & UL & (prox) & $\mathrm{L}>\mathrm{U}$ & $\mathrm{L}>\mathrm{U}$ & $\mathrm{L} \gg>\mathrm{U}$ & $\mathrm{L} \gg>\mathrm{U}$ & NA & no & 7 & 73 & & \\
\hline & & & 03 & $\mathrm{M}$ & 55 & LL & & NA & NA & $\mathrm{NA}$ & NA & NA & NA & 6 & 56 & & \\
\hline & & & 04 & $\mathrm{~F}$ & 75 & LL & & NA & NA & NA & NA & NA & NA & 12 & 76 & & \\
\hline & & & 05 & M & 58 & NA & & NA & NA & NA & NA & NA & NA & 6 & 59 & $63(+1-4)$ & $36(+/-29)$ \\
\hline & L84F & F9S & $\begin{array}{l}01 \\
02 \\
\end{array}$ & $\begin{array}{l}\mathrm{M} \\
\mathrm{F} \\
\end{array}$ & $\begin{array}{l}54 \\
45 \\
\end{array}$ & \begin{tabular}{|l|} 
B \\
LL \\
\end{tabular} & (dysarthria, dysphagia) & $\begin{array}{l}\mathrm{L}=\mathrm{U} \\
\mathrm{NA}\end{array}$ & $\begin{array}{l}\mathrm{L}=\mathrm{U} \\
\mathrm{NA}\end{array}$ & $\begin{array}{l}\mathrm{L}=\mathrm{U} \\
\mathrm{NA}\end{array}$ & $\begin{array}{l}\mathrm{L}=\mathrm{U} \\
\mathrm{NA}\end{array}$ & $\begin{array}{c}4 \\
\text { NA } \\
\end{array}$ & $\begin{array}{l}\text { no } \\
\text { NA }\end{array}$ & $\begin{array}{l}32 \\
35\end{array}$ & $\begin{array}{l}57 \\
48\end{array}$ & $50(+/-5)$ & $34(+1-1)$ \\
\hline & L84V & F10S & 01 & $\mathrm{~F}$ & 58 & LL & (dist) & NA & NA & NA & NA & NA & $\mathrm{NA}$ & 72 & 64 & 58 & 72 \\
\hline & N86S & F11S & 01 & $\mathrm{~F}$ & 57 & LL & (prox) & $\mathrm{L}>\mathrm{U}$ & $\mathrm{L}>\mathrm{U}$ & $\mathrm{L}>\mathrm{U}$ & $\mathrm{L}>\mathrm{U}$ & 4 & no & 21 & 59 & & \\
\hline & & & 02 & $\mathrm{M}$ & 54 & LL & (dist) & $\mathrm{L}>\mathrm{U}$ & $\mathrm{L}>\mathrm{U}$ & $\mathrm{L}>\mathrm{U}$ & $\mathrm{L}>\mathrm{U}$ & 12 & no & 64 & 59 & $56(+1-2)$ & $42(+/-22)$ \\
\hline & G93C & F12S & 01 & $\mathrm{~F}$ & 48 & LL & (dist) & $\mathrm{L}>\mathrm{U}$ & $\mathrm{L}>\mathrm{U}$ & $\mathrm{L}>\mathrm{U}$ & $\mathrm{L}>\mathrm{U}$ & 2 & no & $>110$ & & 48 & \\
\hline & G93A & F13S & 01 & $\mathrm{~F}$ & 42 & $\mathrm{LL}$ & (dist) & $\mathrm{L}>\mathrm{U}$ & $\mathrm{L} \gg \mathrm{U}$ & $\mathrm{L}>\mathrm{U}$ & $\mathrm{L}>\mathrm{U}$ & 0 & no & 31 & 44 & 42 & 31 \\
\hline & G93D & F14S & 01 & $\mathrm{M}$ & 34 & LL & (prox) & $\mathrm{L}=\mathrm{U}$ & $\mathrm{L}<\mathrm{U}$ & NA & NA & 2 & no & 49 & 38 & 34 & 49 \\
\hline & G93V & F15S & 01 & $\mathrm{M}$ & 49 & LL & (prox) & NA & NA & NA & $\mathrm{NA}$ & NA & $\mathrm{NA}$ & $>148$ & & & \\
\hline & V118L & F16S & 01 & $\mathrm{~F}$ & 72 & LL & & NA & NA & NA & NA & NA & NA & 4 & 72 & 72 & 4 \\
\hline & N139D & F17S & $\begin{array}{l}01 \\
02 \\
\end{array}$ & $\begin{array}{l}\mathrm{F} \\
\mathrm{M}\end{array}$ & $\begin{array}{l}58 \\
38 \\
\end{array}$ & \begin{tabular}{|l|l|} 
LL \\
LL \\
\end{tabular} & $\begin{array}{l}\text { (prox) } \\
\text { (dist) }\end{array}$ & $\begin{array}{l}\mathrm{L}>\mathrm{U} \\
\mathrm{L}>\mathrm{U}\end{array}$ & $\begin{array}{l}\mathrm{L}>\mathrm{U} \\
\mathrm{L}>\mathrm{U} \\
\end{array}$ & $\mathrm{L}>\mathrm{U}$ & $\mathrm{L}>\mathrm{U}$ & 5 & $\begin{array}{l}\text { no } \\
\text { no }\end{array}$ & \begin{tabular}{|c|}
190 \\
$>150$ \\
\end{tabular} & 74 & $48(+/-10)$ & 190 \\
\hline & G147D & F18S & 01 & $\mathrm{M}$ & 64 & LL & (dist) & $\mathrm{L}=\mathrm{U}$ & $\mathrm{L}>\mathrm{U}$ & $\mathrm{L}>\mathrm{U}$ & $\mathrm{L}>\mathrm{U}$ & 1 & no & 49 & 68 & & \\
\hline & & & 02 & M & 62 & LL & & NA & NA & $\mathrm{NA}$ & $\mathrm{NA}$ & NA & $\mathrm{NA}$ & 35 & 65 & & \\
\hline & & F19S & 01 & $\mathrm{M}$ & 45 & NA & & NA & NA & NA & NA & NA & no & 18 & 47 & & \\
\hline & & & 02 & $\mathrm{M}$ & 73 & UL & (dist) & NA & NA & NA & NA & NA & NA & 10 & 74 & $61(+1-6)$ & $28(+1-9)$ \\
\hline & I151T & F20S & 01 & $\mathrm{~F}$ & 59 & LL & (dist) & $\mathrm{L}=\mathrm{U}$ & $\mathrm{L}>\mathrm{U}$ & & & & no & & & & \\
\hline & & & 02 & $\mathrm{~F}$ & 70 & LL & (dist) & $\mathrm{L}>\mathrm{U}$ & $\mathrm{L}=\mathrm{U}$ & & & & no & & & & \\
\hline & & & 03 & M & 66 & $\mathrm{LL}$ & (dist) & $\mathrm{L}=\mathrm{U}$ & $\mathrm{L}=\mathrm{U}$ & & & & no & & & $65(+/-3)$ & \\
\hline \multirow{2}{*}{$\overline{A N G}$} & K17I & F21A & 01 & $\mathrm{~F}$ & 47 & LL & (dist) & $\mathrm{L}=\mathrm{U}$ & $\mathrm{L}<\mathrm{U}$ & $\mathrm{L}>\mathrm{U}$ & $\mathrm{L}<\mathrm{U}$ & 17 & no & 27 & 49 & & \\
\hline & & & 02 & $\mathrm{~F}$ & 68 & NA & & NA & NA & NA & NA & NA & NA & 18 & 70 & & \\
\hline \multirow[t]{2}{*}{$V A P B$} & P56S & $\mathrm{F} 22 \mathrm{~V}$ & 01 & M & 54 & LL & (prox) & no & $\mathrm{L}$ & $\mathrm{L}$ & $\mathrm{L}>\mathrm{U}$ & & no & & & & \\
\hline & & & 02 & $\mathrm{~F}$ & 60 & LL & & NA & NA & NA & NA & NA & NA & 144 & 72 & $57(+/-3)$ & 144 \\
\hline TARDBP & G295S & F23T & $\begin{array}{l}01 \\
02\end{array}$ & $\begin{array}{l}\mathrm{F} \\
\mathrm{F}\end{array}$ & $\begin{array}{l}58 \\
61 \\
\end{array}$ & \begin{tabular}{|l}
$\mathrm{B}$ \\
$\mathrm{B}$ \\
\end{tabular} & $\begin{array}{l}\text { (dysarthria) } \\
\text { (dysphagia) }\end{array}$ & $\mathrm{L}=\mathrm{U}$ & $\mathrm{L}=\mathrm{U}$ & $\mathrm{L}=\mathrm{U}$ & $\mathrm{L}=\mathrm{U}$ & 24 & $\begin{array}{c}\text { no } \\
\text { FTD }\end{array}$ & $\begin{array}{c}20 \\
>20\end{array}$ & 59 & $59(+/-2)$ & 20 \\
\hline & A315T & F24T & $\begin{array}{l}01 \\
02\end{array}$ & $\begin{array}{l}\mathrm{M} \\
\mathrm{F}\end{array}$ & $\begin{array}{l}49 \\
74\end{array}$ & \begin{tabular}{|l|} 
UL \\
UL
\end{tabular} & & $\begin{array}{l}\mathrm{L}>\mathrm{U} \\
\mathrm{L}=\mathrm{U}\end{array}$ & $\begin{array}{l}\mathrm{L}>\mathrm{U} \\
\mathrm{L}=\mathrm{U}\end{array}$ & $\begin{array}{l}\text { NA } \\
\text { NA }\end{array}$ & $\begin{array}{l}\mathrm{NA} \\
\mathrm{NA}\end{array}$ & $\begin{array}{l}\text { NA } \\
\text { NA }\end{array}$ & $\begin{array}{l}\text { no } \\
\text { NA }\end{array}$ & $\begin{array}{l}70 \\
48\end{array}$ & $\begin{array}{l}54 \\
78\end{array}$ & $61(+/-12)$ & $59(+/-11)$ \\
\hline & G348C & F25T & 01 & $\mathrm{~F}$ & 30 & \begin{tabular}{|l|} 
UL \\
\end{tabular} & (prox) & $\mathrm{L}>>\mathrm{U}$ & no & $\mathrm{L}>\mathrm{U}$ & $\mathrm{L}=\mathrm{U}$ & $\frac{1 N A}{4}$ & no & $\frac{40}{48}$ & $\frac{10}{34}$ & $01(+t-12)$ & 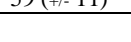 \\
\hline & & & 02 & $\mathrm{~F}$ & 60 & LL & & $\mathrm{NA}$ & NA & $\mathrm{NA}$ & NA & NA & NA & 51 & 64 & & \\
\hline & & & 03 & $\mathrm{~F}$ & 58 & UL & & $\mathrm{L}>\mathrm{U}$ & $\mathrm{L}>\mathrm{U}$ & NA & NA & NA & NA & 46 & 62 & $49(+/-10)$ & $48(+1-2)$ \\
\hline & A382T & F26T & 01 & $\mathrm{~F}$ & 57 & \begin{tabular}{|l|} 
UL \\
\end{tabular} & (prox) & $\mathrm{L}=\mathrm{U}$ & $\mathrm{L}=\mathrm{U}$ & $\mathrm{L}>\mathrm{U}$ & $\mathrm{L}>\mathrm{U}$ & 7 & no & 73 & 63 & & \\
\hline & & F27T & 01 & $\mathrm{~F}$ & 58 & UL & (dist) & $\mathrm{L}=\mathrm{U}$ & $\mathrm{L}=\mathrm{U}$ & $\mathrm{L}>\mathrm{U}$ & $\mathrm{L}<\mathrm{U}$ & 20 & no & 33 & 60 & $57(++0.5)$ & $53(+/-20)$ \\
\hline & G384R & F28T & 01 & $\mathrm{~F}$ & 60 & UL & (dist) & $\mathrm{L} \gg \mathrm{U}$ & $\mathrm{L}=\mathrm{U}$ & $\mathrm{L}=\mathrm{U}$ & $\mathrm{L}>\mathrm{U}$ & 1 & FTD & 63 & 66 & & \\
\hline & & & 02 & $\mathrm{~F}$ & 61 & UL & & $\mathrm{NA}$ & NA & NA & NA & NA & NA & 60 & 56 & & \\
\hline & & & 03 & M & NA & UL & (prox) & NA & NA & NA & NA & NA & NA & NA & 49 & & \\
\hline & & & 04 & $\mathrm{M}$ & 27 & UL & (prox) & NA & NA & NA & NA & NA & NA & 32 & 29 & & \\
\hline & & & 05 & $\mathrm{~F}$ & 68 & LL & (dist) & 0 & $\mathrm{~L} \gg \mathrm{U}$ & & & & & & & $54(+/-9)$ & $52(+/-10)$ \\
\hline & W385G & F29T & 01 & $\mathrm{M}$ & 39 & UL & (dist) & $\mathrm{L}>\mathrm{U}$ & $\mathrm{L}=\mathrm{U}$ & $\mathrm{L}>\mathrm{U}$ & $\mathrm{L}>\mathrm{U}$ & 11 & no & 24 & 41 & & \\
\hline & & & 02 & $\mathrm{M}$ & 31 & LL & (dist) & $\mathrm{L}=\mathrm{U}$ & $\mathrm{L}=\mathrm{U}$ & $\mathrm{L}<\mathrm{U}$ & $\mathrm{L}<\mathrm{U}$ & 15 & no & 84 & 38 & & \\
\hline & & & 03 & $\mathrm{~F}$ & 43 & UL & (dist) & NA & NA & NA & NA & NA & no & 24 & 45 & $38(+/-3)$ & $44(+/-20)$ \\
\hline FUS & R514S & F30F & 01 & $\mathrm{M}$ & 42 & UL & (prox) & $\mathrm{L}>\mathrm{U}$ & $\mathrm{L}>\mathrm{U}$ & $\mathrm{L}>\mathrm{U}$ & $\mathrm{L}>\mathrm{U}$ & 7 & no & 34 & 45 & & \\
\hline & & & 02 & M & 29 & B & (dysarthria) & NA & NA & NA & NA & NA & NA & 27 & 31 & & \\
\hline & & & 03 & $\mathrm{~F}$ & 62 & UL & & NA & NA & NA & NA & NA & NA & 20 & 64 & & \\
\hline & & & 04 & $\mathrm{~F}$ & 49 & UL & & NA & NA & NA & NA & NA & NA & 11 & 50 & & \\
\hline & & & 05 & $\mathrm{M}$ & 61 & LL & & $\mathrm{L}>\mathrm{U}$ & $\mathrm{L}=\mathrm{U}$ & $\mathrm{NA}$ & NA & NA & $\mathrm{NA}$ & 12 & 62 & $49(+1-6)$ & $21(+1-4)$ \\
\hline & R521S & F31F & 01 & $\mathrm{~F}$ & 25 & B & & $\mathrm{L}>\mathrm{U}$ & & $\mathrm{L}>\mathrm{U}$ & $\mathrm{L}>\mathrm{U}$ & NA & no & 15 & 26 & & \\
\hline & & & 02 & M & 54 & LL & (dist) & $\mathrm{L}>\mathrm{U}$ & $\mathrm{L}<\mathrm{U}$ & $\mathrm{L}>\mathrm{U}$ & $\mathrm{L}<\mathrm{U}$ & NA & no & 24 & 56 & & \\
\hline & & & 03 & M & 54 & B & & NA & NA & NA & NA & NA & NA & 21 & 56 & $44(+/-10)$ & $20(+1-3)$ \\
\hline & R521C & $\mathrm{F} 32 \mathrm{~F}$ & 01 & $\mathrm{M}$ & 36 & B & (facial cramps) & $\mathrm{L} \gg>\mathrm{U}$ & $\mathrm{L} \gg \mathrm{U}$ & $\mathrm{L} \gg>\mathrm{U}$ & $\mathrm{L}=\mathrm{U}$ & 5 & no & 14 & 37 & & \\
\hline & & $\mathrm{F} 33 \mathrm{~F}$ & 01 & $\mathrm{M}$ & 39 & $\mathrm{LL}$ & (dist) & $\mathrm{L} \gg>\mathrm{U}$ & $\mathrm{L} \gg \mathrm{U}$ & $\mathrm{L} \gg>\mathrm{U}$ & $\mathrm{L} \gg \mathrm{U}$ & 2 & no & 24 & 41 & & \\
\hline & & & 02 & $\mathrm{~F}$ & 39 & NA & & $\mathrm{NA}$ & $\mathrm{NA}$ & NA & NA & NA & NA & 12 & 40 & & \\
\hline & & $\mathrm{F} 34 \mathrm{~F}$ & 01 & M & 26 & UL & (prox) & $\mathrm{L}>\mathrm{U}$ & $\mathrm{L}=\mathrm{U}$ & $\mathrm{L}>\mathrm{U}$ & $\mathrm{L}=\mathrm{U}$ & 1 & no & 28 & 28 & & \\
\hline & & & 02 & M & 52 & UL & (prox) & NA & NA & NA & NA & NA & NA & & & $35(+/-4)$ & $17(+1-3)$ \\
\hline & R521H & F35F & 01 & $\mathrm{~F}$ & 37 & LL & (dist) & $\mathrm{L}=\mathrm{U}$ & $\mathrm{L}=\mathrm{U}$ & $\mathrm{L}>\mathrm{U}$ & $\mathrm{L}>\mathrm{U}$ & 2 & no & 78 & 44 & & \\
\hline & & & 02 & M & 48 & UL & (prox) & NA & NA & NA & NA & NA & NA & 26 & 50 & & \\
\hline & & & 03 & $\mathrm{~F}$ & 60 & UL & (prox) & $\mathrm{L}=\mathrm{U}$ & $\mathrm{L}=\mathrm{U}$ & $\mathrm{L}>\mathrm{U}$ & $\mathrm{L}>\mathrm{U}$ & 6 & no & 51 & 64 & & \\
\hline & & & 04 & $\mathrm{M}$ & 72 & UL & (prox) & $\mathrm{L}>\mathrm{U}$ & $\mathrm{L}<\mathrm{U}$ & & & & FTD & & & & \\
\hline & & & 05 & $\mathrm{~F}$ & 49 & LL & (dist) & NA & NA & NA & NA & NA & NA & 60 & 54 & & \\
\hline & & & 06 & M & 47 & UL & (prox) & $\mathrm{L}>\mathrm{U}$ & $\mathrm{L}>\mathrm{U}$ & $\mathrm{L}>\mathrm{U}$ & $\mathrm{L}>\mathrm{U}$ & 5 & no & 21 & 49 & & \\
\hline & & & 07 & M & 50 & LL & (prox) & $\mathrm{L}>\mathrm{U}$ & $\mathrm{L}>\mathrm{U}$ & $\mathrm{L}>\mathrm{U}$ & $\mathrm{L}>\mathrm{U}$ & 3 & no & 28 & 52 & $52(+/-4)$ & $44(+1-9)$ \\
\hline
\end{tabular}


Supplementary table 2. Disease characteristics by patient. $M=$ male. $F=$ female. UL=upper limbs. $\mathrm{LL}=$ lower limbs. $\mathrm{B}=$ bulbar. $\mathrm{L}=$ lower motor neuron signs. $\mathrm{U}=$ upper motor neuron signs. NA=information not available. FTD= frontotemporal dementia. $\mathrm{SE}=$ standard error. *: the bulbar score is the difference between initial (at onset) and final (at the last evaluation) bulbar Norris scale. ${ }^{* *}$ : For patients who are still alive (with a disease onset that occurred more than 7 years ago), the duration was expressed as " $>$ the present disease evolution". 
A.

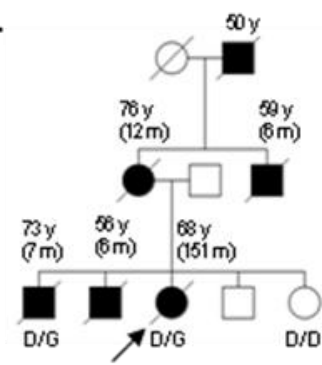

E.

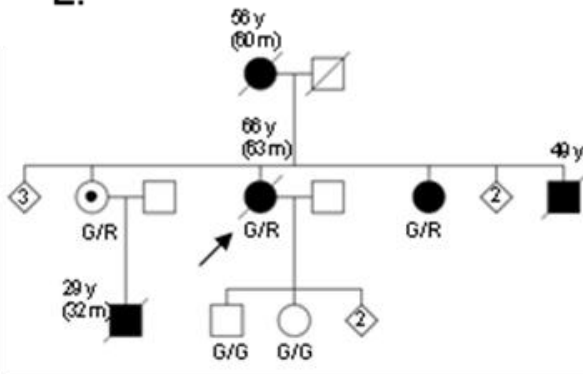

B.

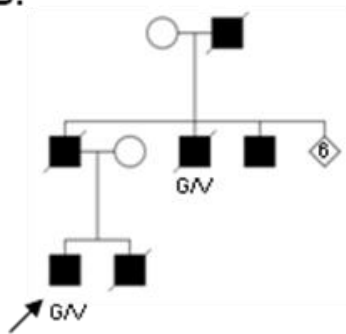

C. $\stackrel{74 y}{(100 m)}$

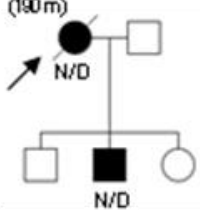

D.

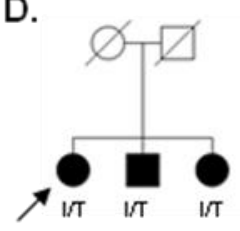

F.

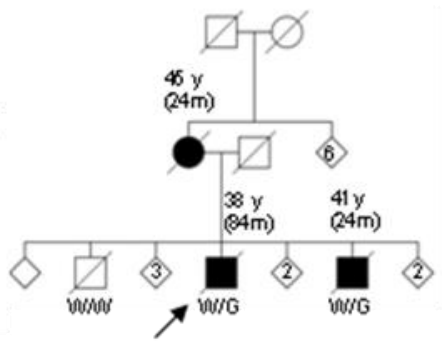

G.

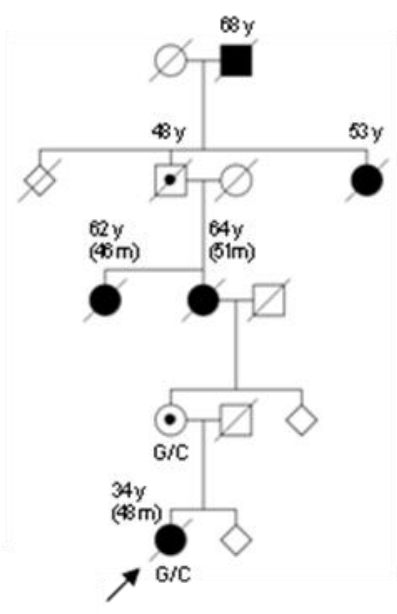

$\mathrm{H}$.

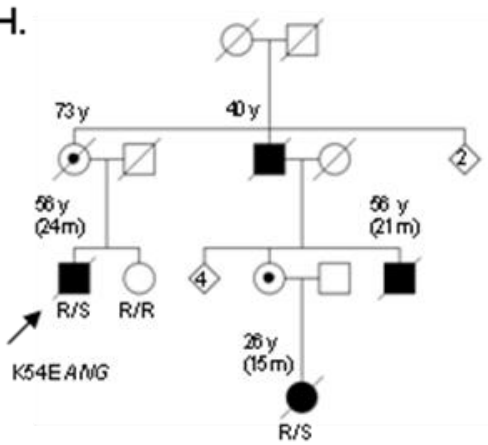

I.

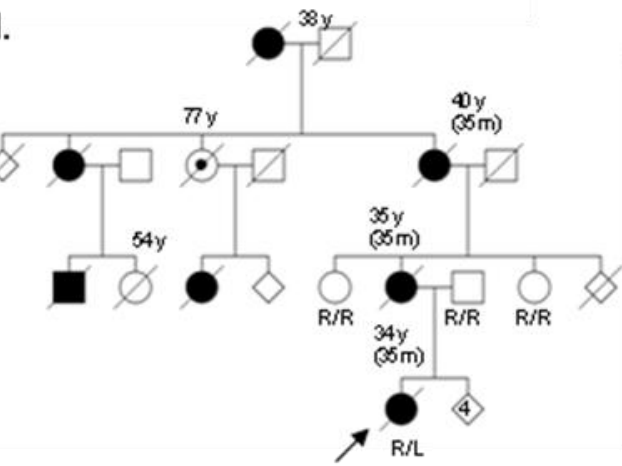

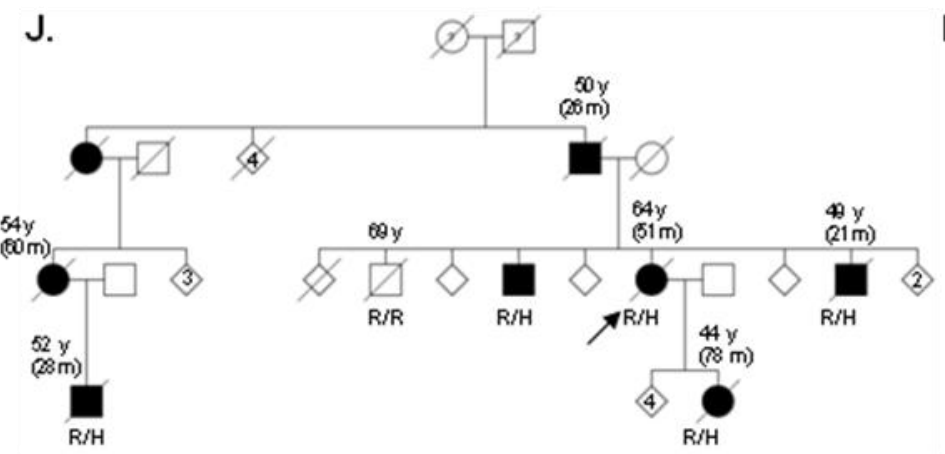

K.

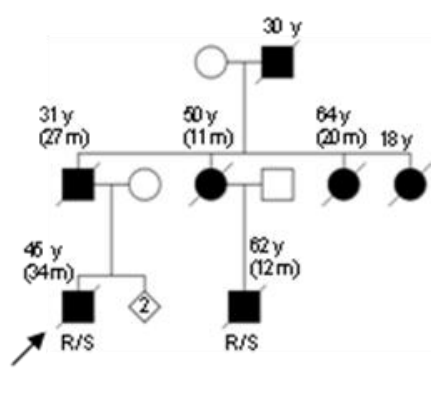

supplementary figure 1. SOD1, TARDBP and FUS mutations segregating with the disease. Pedigree of the F8S, F15S, F17S and F20S families with the D83G (A), G93V (B), N139D (C) and I151T (D) SOD1 mutation. Pedigree of the F28T, F29T and F25T families with the G384R (E), W385G (F) and G348C (G) TARDBP mutations. Pedigree of the F31F, F36F, F35F and F30F families with the R521S (H), R521L (I), R521H (J) and R514S (K) FUS mutations. Arrows indicate index patients. When available, the age at death and the disease duration (in brackets) are indicated above the symbol representing the patients. The genotypes are indicated using a single letter amino acid code below the index case and some relatives for whom DNA was available. 